\title{
PELESTARIAN EKOSISTEM MANGROVE DI TAMAN HUTAN RAYA (TAHURA) NGURAH RAI, DESA SUWUNG, DENPASAR, BALI
}

\author{
Yanti Sugiyanti $^{1}$ dan Oot Hotimah ${ }^{2}$ \\ 1) Mahasiswa Magister Manajemen Lingkungan, Pascasarjana Universitas Negeri Jakarta, Jakarta \\ ${ }^{2)}$ Geografi, Fakultas Ilmu Sosial, Universitas Negeri Jakarta, Jakarta
}

\begin{abstract}
Abstrak
Pelestarian ekosistem mangrove adalah merupakan suatu usaha yang sangat kompleks untuk dilaksanakan, karena kegiatan tersebut sangat membutuhkan suatu sifat akomodatif terhadap segenap elemen yang berada di sekitar kawasan maupun di luar kawasan. Tahura mangrove Ngurah Rai, Denpasar, Bali merupakan kesatuan ekosistem yang memiliki potensi sumberdaya alam pesisir dan laut yang produktif, seperti ekosistem mangrove beserta biota yang hidup di dalamnya yang merupakan sumber bahan makanan, kawasan rekreasi, pariwisata, konservasi dan jenis pemanfaatan lainnya. Penelitian ini bertujuan untuk mengetahui partisipasi masyarakat dalam pelestarian ekosistem mangrove di Tahura Ngurah Rai, Denpasar, Bali. Hasil penelitian menunjukkan bahwa masyarakat berupaya untuk menjaga kelestarian ekosistem mangrove dengan cara menjaga kebersihan di kawasan ekosistem mangrove, ikut aktif dalam kegiatan penanaman mangrove dan pembibitan mangrove serta memberikan dukungan dan penghargaan kepada LSM maupun kelompok masyarkat yang bergerak dalam bidang pelestarian ekosistem mangrove. Hal ini menunjukkan bahwa masyarakat telah menyadari pentingnya keberadaan ekosistem mangrove bagi kawasan pesisir pantai.
\end{abstract}

Kata Kunci: ekosistem mangrove, partisipasi masyarakat, pelestarian

\begin{abstract}
Conservation of mangrove ecosystems is a very complex undertaking to be undertaken, as these activities desperately require an accommodative characteristic of all the elements that are in the area as well as outside the region. Tahura mangrove Ngurah Rai, Denpasar, Bali is a unified ecosystem that has the potential of coastal and marine natural resources that are productive, such as mangrove ecosystem along with biota living in it which is a source of food, recreation area, tourism, conservation and other types of utilization. This study aims to determine the community participation in the conservation of mangrove ecosystems in Tahura Ngurah Rai, Denpasar, Bali. Result of research indicate that mangrove conservation effort done by community is by keeping cleanliness in mangrove ecosystem area, actively participate in mangrove planting activity and mangrove seedling and give support and appreciation to NGO or community group that active in conservation of mangrove ecosystem. This shows that the community has realized the importance of the existence of mangrove ecosystems for coastal areas.
\end{abstract}

Key words: mangrove ecosystem, community participation, conservation 
PENDAHULUAN

Kota Denpasar merupakan Ibu kota provinsi Bali. Pada sektor pariwisata, Kota Denpasar juga memiliki potensi yang cukup besar, dibandingkan daerah yang lainnya. Salah satu potensi wisata yang dimiliki oleh Kota Denpasar yakni ekosistem mangrove. Ekosistem mangrove di kawasan Bali ditetapkan menjadi Taman Hutan Raya (Tahura) berdasarkan berdasarkan SK. Menhut No. 544/Kpts-II/1993 tanggal 25 September 1993, namun masyarakat lebih mengenalnya dengan Mangrove Information Center (MIC). Tahura mangrove Bali memiliki luas luas $1.353 \mathrm{Ha}$ yang terbentang dari Sanur hingga Tanjung Benoa. Obyek wisata mangrove Bali ini setiap harinya ramai dikunjungi oleh para wisatawan, baik warga setempat maupun wisatawan yang berasal dari luar daerah.

Taman hutan raya mangrove Desa Suwung Bali yang memiliki luas 102,22 ha merupakan kesatuan ekosistem yang memiliki potensi sumberdaya alam pesisir dan laut yang produktif, seperti ekosistem mangrove beserta biota yang hidup di dalamnya yang merupakan sumber bahan makanan, kawasan rekreasi, pariwisata, konservasi dan jenis pemanfaatan lainnya. Lokasi ini pada awalnya merupakan tambak udang, hingga pada tahun 1990 pemerintah daerah yang bekerjasama dengan JICA melakukan penanaman mangrove dengan tujuan sebagai salah satu percontohan hutan mangrove nasional. Untuk dapat menjelajah hutan mangrove dilokasi ini pengelola telah menyediakan salah satu sarana bagi pengunjung yakni tracking mangrove dengan panjang $1,3 \mathrm{~km}$.

Ekosistem mangrove merupakan tipe ekosistem khas yang terdapat di sepanjang pantai atau muara sungai yang dipengaruhi pasang surut air laut (Muharam, 2014). Hutan mangrove banyak dijumpai di wilayah pesisir yang terlindung dari gempuran ombak dan daerah yang landai. Mangrove tumbuh optimal di wilayah pesisir yang memiliki sungai besar dan delta yang aliran airnya banyak mengandung lumpur. Sedangkan di wilayah pesisir yang tidak bermuara sungai, pertumbuhan vegetasi mangrove tidak optimal. Mangrove sulit tumbuh di wilayah pesisir yang terjal dan berombak besar dengan arus pasang surut yang kuat, karena kondisi ini tidak memungkinkan terjadinya pengendapan lumpur yang diperlukan sebagai substrat bagi pertumbuhannya (Dahuri, 2003).

Pelestarian ekosistem mangrove adalah merupakan suatu usaha yang sangat kompleks untuk dilaksanakan, karena kegiatan tersebut sangat membutuhkan suatu sifat akomodatif terhadap segenap elemen yang berada di sekitar kawasan maupun di luar kawasan. Salah satu strategi 
yang dapat diterapkan dalam konteks pengelolaan ekosistem hutan mangrove adalah pengelolaan berbasis masyarakat (Community Based Management). Dahuri et al (2001) mengemukakan bahwa pengelolaan berbasis masyarakat mengandung arti keterlibatan langsung masyarakat dalam mengelola sumberdaya alam di suatu kawasan. Hal ini berarti masyarakat juga ikut aktif dalam upaya pelestarian sumberdaya alam di suatu kawasan.

Penelitian yang dilakukan oleh Zainudin et al (2015) menunjukkan bahwa perilaku masyarakat pesisir Kabupaten Pangkep dalam pelestarian hutan mangrove tergolong dalam kategori sedang. Faktorfaktor yang berhubungan dengan perilaku masyarakat dalam pengelolaan hutan mangrove secara lestari adalah intensitas penyuluhan dan dukungan lingkungan. Penelitian lainnya yang dilakukan oleh Abdullah et al (2014) menunjukkan bahwa masyarakat memiliki kemauan untuk berpartisipasi dalam rehabilitasi mangrove. Sikap ini memiliki korelasi dengan jenis kelamin, pendidikan, ras, manfaat dan resiko yang dirasakan dalam rehabilitasi mangrove. Selain itu, penelitian yang dilakukan oleh Salampessy et al (2015) menunjukkan bahwa orang mampu beradaptasi dan memodifikasi lingkungan sebagai bentuk modal budaya yang dimiliki. Masyarakat menerapkan pengetahuan ekologi tradisional dan mendirikan institusi agar konservasi hutan bakau tetap terjaga. Pemerintah dapat mengakomodasi modal budaya dalam kebijakan pembangunan dan konservasi kawasan pesisir.

Dalam pengelolaan dan pelestarian hutan mangrove, menurut Bengen (2001) terdapat dua konsep utama yang dapat diterapkan yaitu perlindungan hutan mangrove dan rehabilitasi hutan mangrove. Salah satu cara yang dapat dilakukan dalam rangka mengupayakan perlindungan terhadap keberadaan hutan mangrove adalah dengan menunjuk suatu kawasan mangrove untuk menjadi kawasan hutan konservasi, dan suatu bentuk sabuk hijau di sepanjang pantai dan tepi sungai.

Tujuan penelitian ini adalah untuk mengetahui upaya apa saja yang dilakukan masyarakat dalam pelestarian ekosistem mangrove. Penelitian serupa telah dilakukan oleh Nwosu dan Holzlöhner (2016) di kawasan mangrove Nigeria dan di dapatkan salah satu upaya yang diperlukan dalam pelestarian dan pemulihan ekosistem mangrove Nigeria adalah melembagakan program restorasi hutan bakau dengan mekanisme pemantauan dan evaluasi yang diperlukan, dan mempromosikan kesadaran masyarakat (pendekatan berbasis mayarakat). 


\section{METODOLOGI}

Penelitian dilaksanakan pada tanggal 11-14 Mei 2018 di Desa Suwung Kauh, Denapasar Selatan, Bali. Desa Suwung Kauh dipilih menjadi lokasi penelitian karena lokasi ini merupakan lokasi dimana Tahura Mangrove berada. Teknik analisis yang digunakan dalam penelitian ini adalah wawancara dan kuesioner. Populasi dari penelitian ini adalah warga Desa Suwung. Sampel dalam penelitian ini sebanyak 20 responden. Teknik sampling yang digunakan untuk penentuan sampel adalah random sampling yaitu pengambilan sampel secara acak.

Teknik analisis data pada penelitian ini menggunakan penentuan skoring kriteria kuesioner (skala pengukuran mirip skala likert). Skala Likert merupakan alat untuk mengukur (mengumpulkan data dengan cara "mengukur-menimbang") yang "itemnya" (butir-butir pertanyaannya) berisikan (memuat) pilihan yang berjenjang. Adapun skala yang digunakan dalam penelitian kali ini adalah 5,4,3,2,1 untuk masing-masing kategori jawaban yakni Sangat sering, Sering, Kadang-kadang, Jarang dan Tidak Pernah.

Rumus presentase yang digunakan sebagai berikut:

$$
P=\frac{\mathrm{F}}{\mathrm{n}} \times 100 \%
$$

\section{Keterangan:}

P: Bilangan yang akan dicari

F: Jumlah frekuensi jawaban

$\mathrm{n}$ : Banyaknya responden

Selanjutnya menggunakan patokan kategori Menurut Ali (1985) pengolahan data hasil penelitian di analisis secara kualitatif, untuk mengetahui skor rata-rata jawaban responden digunakan rumus perhitungan sebagai berikut:

$Y=\frac{\Sigma \mathrm{Y}}{\mathrm{n}}$

Keterangan:

Y: Jumlah skor rata-rata jawaban responden $\Sigma \mathrm{Y}$ : Total skor jawaban responden

$\mathrm{n}$ : jawaban responden

Untuk mengetahui secara tepat tingkat presentase jawaban digunakan rumus perhitungan sebagai berikut:

Persentase (\%)

$=\frac{\text { Jumlah skor rata }- \text { rata responden }}{\text { Jumlah skor jawaban responden }} \times 100 \%$

Data yang diperlukan adalah data primer diperoleh melalui observasi, dokumentasi dan wawancara serta data 
sekunder diperoleh melalui instansi terkait dan bahan pustaka (literature).

\section{HASIL DAN PEMBAHASAN}

Dari 20 responden, $45 \%$ menjawab tidak pernah acuh terhadap kebersihan di kawasan ekosistem mangrove, sedang $11 \%$ lainnya menjawab hampir tidak pernah (jarang) acuh apabila melihat sampah yang tersangkut pada akar tanaman mangrove. $19 \%$ responden sangat sering merasakan tidak nyaman apabila melihat ada yang membuang sampah sembarangan di kawasan sekitar mangrove, 16\% lainnya menjawab sering mengajak warga untuk menjaga kebersihan hutan mangrove. Hanya $12 \%$ responden yang menjawab kadangkadang berusaha untuk menjaga kebersihan di sekitar kawasan ekosistem mangrove dalam kurun waktu 2 tahun terakhir. Meski demikian, terlihat bahwa sebagian masyarakat peduli terhadap kebersihan di kawasan ekosistem mangrove.

Dari 20 responden, 23\% menjawab tidak pernah segan untuk mengeluarkan dana guna kegiatan penanaman mangrove, sebanyak $25 \%$ responden menjawab sering berpartisipasi pada setiap kegiatan penanaman mangrove, sebanyak $24 \%$ responden menjawab sangat sering mengikuti program penanaman mangrove secara sukarela (tanpa paksaan) dan sebanyak $17 \%$ responden menjawab kadang menyisihkan uangnya untuk ikut dalam program pembibitan mangrove. Hanya $11 \%$ responden yang menjawab jarang melakukan penanaman kembali jika mereka melihat ada tanaman mangrove yang mati atau rusak hal ini berarti masyarakat sangat peduli dan mau ikut berpartisipasi dalam upaya pelestarian ekosistem mangrove. Hal ini terlihat dari besarnya persentase masyarakat yang dengan sukarela mengeluarkan dana dan ikut aktif dalam kegiatan penanaman dan pembibitan mangrove.

Dari 20 responden, sebanyak 20\% dan $19 \%$ menyatakan sangat sering memberikan kritik jika ada yang melakukan perusakan mangrove yang bukan bertujuan untuk pemanfaatan dan sering memberikan penyuluhan mengenai sistem tebang pilih jika akan memanfaatkan tanaman mangrove. Selain itu $28 \%$ responden diantaranya menyatakan kadang-kadang bersedia meluangkan waktunya untuk menjelaskan pentingnya fungsi ekosistem mangrove. Meskipun masih jarang masyarakat yang memberikan saran tentang program pelestarian mangrove, yakni hanya sebanyak $17 \%$ bahkan $16 \%$ responden mengaku tidak pernah menggagas komunitas peduli mangrove. Namun demikian, sebagian besar masyarakat sudah mulai mengerti pentingnya fungsi dan kelestarian ekosistem mangrove bagi kawasan pesisir pantai. 
Dari 20 responden $45 \%$ diantaranya sangat sering memberikan dukungan kepada UKM yang memanfaatkan bahan dari tanaman mangrove untuk meningkatkan perekonomian tentunya dengan bijak serta sering memberikan dukungan kepada LSM maupun kelompok masyarakat yang bergerak di bidang pelestarian ekosistem mangrove (33\% responden). Dukungan masyarakat dalam program pelestarian mangrove dapat telihat dengan banyaknya responden yang menyatakan tidak pernah tidak peduli jika program pelestarian mangrove tidak berjalan dengan baik yakni sebanyak $19 \%$ responden, sebanyak $2 \%$ responden menyatakan kadang-kadang memberikan apresiasi kepada masyarakat dalam upaya pelestarian mangrove dan sisanya sebanyak $1 \%$ menyatakan jarang menyetujui apapun kegiatan yang bertujuan untuk melestarikan ekosistem mangrove. Dari hal tersebut diatas terlihat bahwa masyakarat sangat memberikan dukungan terhadap kegiatan dan upaya yang berkaitan dengan pelestarian ekosistem mangrove.

Kepedulian masyarakat terhadap kebersihan di kawasan ekosistem mangrove cukup besar hal ini didukung dari sikap masyarakat yang mau berusaha untuk menjaga kebersihan di kawasan ekosistem mangrove dengan tidak membuang sampah sembarangan, berupaya untuk mengambil sampah yang tersangkut pada akar mangrove, dan bersama-sama mengajak seluruh elemen masyarakat untuk menjaga kebersihan.

Pada umumnya masyarakat sudah terlibat aktif dalam upaya pelestarian ekosistem mangrove seperti penanaman, pemeliharaan, dan pengelolaan ekosistem mangrove. Hal ini didukung dengan kesediaan masyarakat dalam memberikan dukungan baik moril, materil maupun tenaga dalam upaya pelestarian ini.

Masyarakat menyadari bahwa meningkatnya abrasi pantai maupun berkurangnya tangkapan ikan dikarenakan semakin berkurangnya ekosistem mangrove. Hal ini berarti masyarakat sudah mengerti betapa pentingnya keberadaan ekosistem mangrove bagi kawasan pesisir pantai. Bahkan masyarakat mengetahui salah satu program pelestarian ekosistem mangrove yang berbasis ekowisata, dimana program tersebut memiliki manfaat baik bagi ekologi maupun perekonomian masyarakat sekitar.

Masyarakat sangat mendukung apabila ada LSM maupun kelompok masyarakat yang bergerak dalam bidang pelestarian ekosistem mangrove, dan memberikan perhatian lebih kepada program pelestarian (penanaman, pemeliharaan dan pengelolaan) agar dapat berjalan sebagaimana mestinya. Bahkan masyarakat mendukung keberadaan UKM 
yang memanfaatkan bahan dari tanaman mangrove (akar, buah, daun dan batang) sesuai dengan peruntukkannya.

\section{KESIMPULAN}

Berdasarkan hasil penelitian dan pembahasan di atas maka dapat ditarik kesimpulan Upaya masyarakat dalam pelestarian ekosistem mangrove diantaranya adalah dengan menjaga kebersihan di kawasan ekosistem mangrove, ikut aktif dalam kegiatan penanaman mangrove serta kegiatan pembibitan mangrove.

Pengetahuan masyarakat mengenai pentingnya keberadaan ekosistem mangrove dan pentingnya upaya pelestarian ekosistem mangrove sudah sangat mendukung.

Masyarakat memberikan apresiasi kepada LSM maupun kelompok masyarakat yang bergerak dalam bidang pelestarian ekosistem mangrove, serta berperan aktif dalam mengawasi jalannya kegiatan pelestarian ekosistem mangrove.

\section{DAFTAR PUSTAKA}

Abdullah K, A.M Said and D. Omar. 2014. Community-Based Conservation in Managing Mangrove Rehabilitation in Perak and Selangor. J. ProcediaSocial and Behavioral Science,153: 121-31.
Ali M. 1985. Penelitian Kependidikan (Prosedur dan Strategi). Penerbit Angkasa Bandung. Bandung.

Bengen D.G. 2001. Pengenalan dan Pengelolaan Ekosistem Mangrove. PKSPL - IPB, Bogor.

Dahuri, R., J. Rais, S.P. Ginting dan M.J. Sitepu. 2001. Pengelolaan Sumberdaya Wilayah Pesisir dan Lautan secara Terpadu. Pradnya Paramita, Jakarta.

Dahuri, R. 2003. Keaneka Ragaman Hayati Laut: Aset Pembangunan Berkelanjutan Indonesia, PT. Gramedia Pustaka Umum. Jakarta.

Muharam. 2014. Penanaman mangrove sebagai salah satu upaya rehabilitasi lahan dan lingkungan di kawasan pesisir pantai utara Kabupaten Karawang. J. Ilmiah Solusi, 1(1):114.

Nwosu F.M, and S. Holzlöhner. 2016. Suggestions for the Conservation and Rehabilitation of Nigeria's Mangrove Ecosystem. J. of Ecosystem \& Ecography, 6(1): 1-3

Salampessy M.L, I.G. Febryano, E. Martin, M.E. Siahaya and R. Papilaya. 2015. Conservation in the Coastal areas of Ambon Dalam Bay, Moluccas, Indonesia. J. Procedia Environmental Science, 23: 222-29.

Zainudin S, Sumardjo dan D Susanto. 2015. Perilaku masyarakat dalam pelestarian hutan mangrove di Kabupaten Pangkep Provinsi 
Sulawesi Selatan. J. Penyuluhan, 11(1): 91-100 